Saudi Journal of Oral and Dental Research

Abbreviated Key Title: Saudi J Oral Dent Res

ISSN 2518-1300 (Print) |ISSN 2518-1297 (Online)

Scholars Middle East Publishers, Dubai, United Arab Emirates

Journal homepage: https://saudijournals.com

Original Research Article

\title{
Influence of Serum Vitamin D on Oral Lichen Planus: A Systematic Review
}

Nilofer J Adhiraja $^{1 *}$, Deepak Daryani ${ }^{2}$, Chikku Shaila John ${ }^{1}$

${ }^{1}$ Oral Medicine and Radiology Post Graduate, Malabar Dental College and Research Centre Manoor, Chekanoor Road, Mudur P.O Edappal, Malappuram, Kerala, India

${ }^{2}$ Professor \& HOD of Department of Oral Medicine and Radiology, Malabar Dental College and Research Centre Manoor, Chekanoor Road, Mudur P.O Edappal, Malappuram, Kerala, India

DOI: $10.36348 /$ sjodr.2020.v05i12.005

| Received: 02.12.2020 | Accepted: 14.12.2020 | Published: 18.12.2020

*Corresponding author: Nilofer J Adhiraja

\section{Abstract}

Oral lichen planus is a chronic autoimmune mucocutaneous disorder affecting skin and mucosa of various parts of the body which is of an unspecific cause purpose of this study is to assess the role of vitamin $\mathrm{D}$, which is now considered to be a causative factor in the development of the disease. The assessment is done through analysing various studies that were done and proven the association of vitamin D and lichen planus. In this review study, articles were collected from google scholar, pubmed, scopus and science direct. Out of data screening, 13 articles were found to be eligible for including in our study. According to our study vitamin D is found to be a risk factor in oral lichen planus.

Keywords: Oral lichen planus, vitamin D receptors, lipopolysaccharides, serum 25 hydroxy vitamin D, VDR gene, electrochemiluminescence, topical steroids.

Copyright () 2020 The Author(s): This is an open-access article distributed under the terms of the Creative Commons Attribution 4.0 International License (CC BY-NC 4.0) which permits unrestricted use, distribution, and reproduction in any medium for non-commercial use provided the original author and source are credited.

\section{INTRODUCTION}

Oral lichen planus (OLP) is a common mucocutaneous disease and is thought to affect $0.5 \%$ $1 \%$ of the world's population. This condition can affect either skin or mucosa or both. It can cause bilateral white striations, papules, or plaqueson the buccal mucosa, tongue, and gingiva. Erythema, erosions and blisters may or may not be present. The involvement of the oral mucous membrane accompanies or precedes the appearance of lesions on the skin and genital mucous membrane. Oral lichen planus can be classified into 3 types based on clinical appearance: reticular (white lines, papules or plaques), erythematous (atrophic) and erosive (ulcerated or bullae type). Among these erythematous and erosive types are found to be associated with pain. OLP is a $\mathrm{T}$ cell mediated autoimmune disease with complex etiopathogenesis. Cytotoxic CD8+ T cells trigger the apoptosis of oral epithelial cells. However, precise cause of OLP is unknown. Vitamin D, also known as calciferol is a fat soluble vitamin which is naturally present in few foods, or available as dietary supplements. It is also produced endogenously. When the ultraviolet rays enters the skin, vitamin D synthesis occurs in the body. Serum vitamin $\mathrm{D}$ level is considered to be a biomarker in the overall health of an individual (Table-1).

Table-1

\begin{tabular}{|l|l|l|}
\hline $\mathbf{n m o l} / \mathbf{L}$ & $\mathbf{n g} / \mathbf{m L}$ & Health status \\
\hline$<30$ & $<12$ & Vitamin D deficiency \\
\hline $30-50$ & $12-20$ & Inadequate for bone and overall health \\
\hline$>50$ & $>20$ & Considered adequate for bone and overall health \\
\hline$>125$ & $>50$ & Potential adverse effects \\
\hline
\end{tabular}

Vitamin D promotes 25(OH)D (Vit D) promotes differentiation of epithelial cells and also prevents inappropriate apoptosis and upregulation of inflammatory cytokines in keratinocytes differentiation of epithelial cells. Vitamin D inhibits autoimmune disorders because it has immunosuppressive and immunomodulatory effects. It inhibits the antigen presentation to $\mathrm{T}$ lymphocytes. Also stimulates the regulatory effect of $\mathrm{T}$ cells, diminishes $\mathrm{B}$ lymphocyte differentiation and immunoglobulin secretion. Vitamin $\mathrm{D}$ helps in mediating pro-inflammatory factors and VDR insufficiency is associated with excessive cytokines. vitamin D receptors (VDRs) encoded by VDR gene (chromosomal location 12q12-14) play an 
important role in regulating vitamin $\mathrm{D}$. Based on that it is speculated that VDR gene polymorphisms may be related to OLP. Vitamin D is found to have potential therapeutics benefit in autoimmune diseases, psoriasis and neoplasm. Various case control studies have been conducted, where OLP patients and healthy individuals with similar age group, health status and socioeconomic background were selected. Those study results have proven significant association of Vitamin D levels and OLP. Identification of this role helps in developing new preventive and therapeutic methods in management of OLP.

\section{MATERIALS AND METHOD}

For the present study, articles related to vitamin D and OLP in English language was obtained from google scholar, pubmed, science direct and scopus. There was a total of 196 records, out of that only 13 is considered to be valid for our study (Figure1). Articles that were included in our study was based on 3 criteria. Those articles that conducted a) a casecontrol study, where OLP patients and healthy individuals with matching age, gender, socioeconomic background were selected b) study on therapeutic effect of Vitamin D on OLP 3) molecular level study for assessing VDR gene polymorphism and susceptibility to OLP. Articles that are excluded from our study include a) cutaneous lichen planus b) patients under medication for OLP b) patients with metabolic and bone diseases.

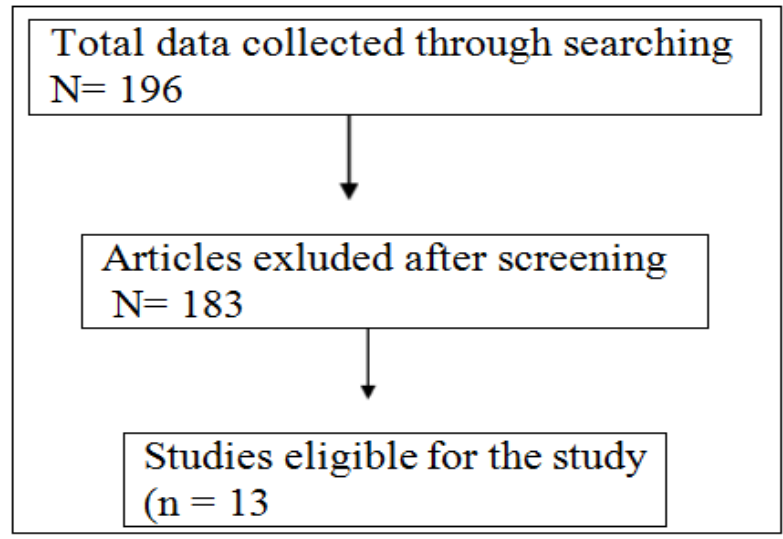

Fig-1:

\section{RESULTS}

\section{a) Studies on serum vitamin D levels}

Out of 13 articles we have selected, 6 of them are case-control study, where $5 \mathrm{ml}$ of blood sample was collected from OLP patients and healthy individuals, using electrochemiluminescence technique. In all the studies serum vitamin D levels are lesser in patients with OLP compared to non OLP individuals. Among that 3 studies showed a statistically significant association (Table-2).

Table-2

\begin{tabular}{|l|l|}
\hline Author & Result \\
\hline Ahmed et al., & $\begin{array}{l}40 \text { cases and } 40 \text { controls were selected. Serum vit D in cases and controls are 18.84+12.69 and } \\
31.28+13.58 \text { repectively. }\end{array}$ \\
\hline Golizadeh et al., & $\begin{array}{l}65 \text { cases and } 45 \text { controls were included in the study. Serum and salivary levels of vitamin D } \\
\text { evaluated. Salivary vitamin D was lower in cases, but there is no significant differences in serum } \\
\text { vitamin D levels of cases and controls }\end{array}$ \\
\hline Gupta et al., & $\begin{array}{l}102 \text { cases and 102 controls were included in the study. A statistically significant difference in } \\
\text { serum vitamin D levels were noted. The mean levels were 20.40 ng/ml and 32.67 ng/ml in cases } \\
\text { and control groups respectively }\end{array}$ \\
\hline Bahramian et al., & $\begin{array}{l}\text { Among 18 cases and 18 controls ,the levels of serum vitamin D was lower in cases but not } \\
\text { statistically significant }\end{array}$ \\
\hline Muzaffar et al., & $\begin{array}{l}\text { 20 cases and 20 controls were included in the study, where 40\% of the OLP group had decreased } \\
\text { serum vitamin D levels and only 10\% of control group had decreased vitamin D levels which is } \\
\text { statistically significant }\end{array}$ \\
\hline Thum-Tyzo et al., & $\begin{array}{l}\text { Among 53 olp patients, 84.9\% had insufficient levels of serum vitamin D, and 15.1\% had } \\
\text { deficient serum vitamin D }\end{array}$ \\
\hline
\end{tabular}

\section{b) Studies on therapeutic effects of vitamin D on OLP}

3 articles in our study is based on assessing the outcome of vitamin D supplementation in OLP patients. Results are mentioned in the Table- 3 . In a case report by Varma et al., 40-year female with erosive OLP and multiple joint \& muscle disorder was diagnosed with reduction in serum calcium and vitamin D levels. They adviced Kenacort cream $0.1 \%$ \& administered cholecalciferol 300,000 units IM. There was significant improvement in erythematous desquamated area, and burning sensation was completely absent after 2 weeks. In their department another case of 45 years and 23 year old female reported with similar findings. And on blood investigation there was reduction in serum calcium and vitamin D levels. 
Table-3

\begin{tabular}{|c|c|c|}
\hline Author & Method & Result \\
\hline $\begin{array}{l}\text { Razi et } \\
\text { al., }\end{array}$ & $\begin{array}{l}100 \text { perimenopausal women with OLP with serum vitamin D } \\
\text { level below } 30 \mathrm{ng} / \mathrm{ml} \text { were divided into two groups ; Group A } \\
\text { were provided conventional therapy and Group B was given } \\
\text { conventional + vitamin D. }\end{array}$ & $\begin{array}{l}\text { Group A and B has similar reduction in } \\
\text { pain intensity, but clinical improvement } \\
\text { of the lesion by } 4^{\text {th }} \text { week of treatment } \\
\text { was significant in Group B }\end{array}$ \\
\hline $\begin{array}{l}\text { Nazeer } \\
\text { et al., }\end{array}$ & $\begin{array}{l}450 \text { OLP patients with } 35-55 \text { years of age who has not } \\
\text { undergone treatment was selected for the study. Divided into } 3 \\
\text { groups based on vitamin D level and stress. } \\
\text { Group } 1 \text { was provided with topical steroids, vitamin D } \\
\text { Supplements, psychological counselling } \\
\text { Group } 2 \text { was given topical steroids and vitamin D Supplements. } \\
\text { Group } 3 \text { was given topical steroids only }\end{array}$ & $\begin{array}{l}\text { significant improvement in both group I } \\
\text { and II patients compared to group III } \\
\text { patients. vitamin D supplements weekly } \\
\text { had improvement in burning sensation }\end{array}$ \\
\hline $\begin{array}{l}\text { Gupta et } \\
\text { al., }\end{array}$ & $\begin{array}{l}102 \text { OLP patients were included in the study based on clinical or } \\
\text { clinicopathological criteria. They were divided into } 3 \text { groups. } \\
\text { Group } 1 \text { was given topical steroids and psychological } \\
\text { Counselling } \\
\text { Group } 2 \text { was given topical steroids and vitamin D supplements } \\
\text { Group } 3 \text { was given topical steroids, vitamin D supplements, } \\
\text { and psychological counseling }\end{array}$ & $\begin{array}{l}\text { statistically significant improvement in } \\
\text { both subjective and objective symptoms } \\
\text { in patients who were supplemented with } \\
\text { vitamin D with or without } \\
\text { psychological counseling apart from } \\
\text { topical steroid application was noted }\end{array}$ \\
\hline
\end{tabular}

\section{c) Molecular level study}

3 studies were based on molecular level analysis of vitamin D and OLP (Table-4). In one study, isolation of DNA from blood of OLP patients was done and Vitamin D receptor (VDR) gene was evaluated to know whether gene polymorphism is associated with susceptibility to OLP.

\begin{tabular}{|l|l|l|}
\hline Author & Method & Result \\
\hline Shen et al., & $\begin{array}{l}\text { 147 cases and 207 controls were included in the study. } \\
\text { DNA isolation from blood and genotyping was done }\end{array}$ & $\begin{array}{l}\text { VDR gene is associated } \\
\text { with OLP susceptibility }\end{array}$ \\
\hline Zhao et al., & $\begin{array}{l}\text { 14 OLP patients were undergone biopsy to evaluate } \\
\text { whether liposaccharide (LPS) is responsible for VDR } \\
\text { gene reduction }\end{array}$ & $\begin{array}{l}\text { LPS induced reduction in VDR in OLP } \\
\text { biopsies compared with normal ones }\end{array}$ \\
\hline Du et al., & $\begin{array}{l}\text { H\&E staining, myeloperoxidase assays, western blot and } \\
\text { quantitative PCR was done on human biopsies and serum } \\
\text { of OLP patients to evaluate the status of VDR }\end{array}$ & $\begin{array}{l}\text { Lack of VDR in diseased biopsies and } \\
\text { LPS induced cytokine production causing } \\
\text { apoptosis of keratinocytes. }\end{array}$ \\
\hline
\end{tabular}

\section{DISCUSSION}

The results of our study based on several articles shows that vitamin $\mathrm{D}$ play a role in development of oral lichen planus. Reduction in Vitamin D level is found to be associated with initiation and severity of the disease because it has immunosuppressive and anti-inflammatory properties which inhibits development of autoimmune disorders $[3,7]$. It prevents the apoptosis of keratinocytes by preventing antigen presentation to $\mathrm{T}$ lymphocytes by regulating the cytokine production. Genetic predisposition, environmental and epidemiological factors are the factors contributing initiation of autoimmune disorders. Deficient Vitamin D levels in blood and higher incidence of autoimmune disorders like pemphigus vulgaris (PV), systemic lupus erythematosis, rheumatoid arthritis were noted [1] studies were conducted on serum vitamin D levels and pemphigus vulgaris by El-Komy et al and Joshy et al., The serum vitamin D levels were lower in PV patients than healthy control group thus indicating insufficiency of vitamin D could be a predisposing factor in PV and exacerbates the autoimmune condition [7]. The contribution of vitamin $\mathrm{D}$ in lichen planus can be supported by Van Belle et al., who reviewed the role of vitamin $\mathrm{D}$ in other autoimmune conditions like rheumatoid arthritis, SLE, diabetes mellitus type 1 etc [1]. Increase in deficiency of vitamin D is mainly because of decreased sun exposre among population. And people are not aware of it until they get tested. This hypothesis may explain why people become more susceptible to autoimmune diseases, because vitamin D level play a role in it.

Various studies were done to assess the effect of vitamin D in treatment of OLP. Positive results in terms of clinical presentation and pain intensity were shown in OLP patients who were supplemented with vitamin $\mathrm{D}$ compared to those undergone conventional therapy alone based on studies by Nazeer et al., and Razi et al., [2, 5]. There was improvement in subjective and objective complaints. In study conducted by Gupta et al., psychological counselling was also done in stressed OLP patients because stress also could increase the severity of the disease, and this showed great results [8]. In a case report by Varma et al 40-year-old female 
showed marked improvement in severe erosive lichen planus after she was injected 300,000 units of cholecalciferol intramuscularly. Thus, therapeutic efficacy shows the relationship of deficient vitamin D and initiation and progression OLP.

In 2016, Zhang et al., suggested that vitamin D facilitate anti-inflammatory properties in OLP. Thus, vitamin D supplement could be a promising technique for OLP management [10] study conducted by Shen et al., aimed to explore the effects of genetic variation in the VDR gene and related environmental factors on OLP susceptibility in Chinese Han population. The results showed that VDR rs2239185-TT and rs7975232CC increased the susceptibility to OLP. In a study conducted by Zhao et al., Lipopolysaccharise induced reduction in vitamin $\mathrm{D}$ receptor (VDR) expression in mucosal cells depending on TNF $\alpha$-miR346 signaling was found vitamin D/ VDR can inhibit LPS-induced keratinocytes apoptosis by adjusting $\mathrm{NF}-\kappa \mathrm{B}$ stream [13]. Considering the inadequate levels of VDR observed in OLP patients, targeting VDR expression in oral epithelial cells can be a useful method for OLP management $[10,13]$.

\section{CONCLUSION}

Serum vitamin D is found to be a contributing factor in OLP. Thus in addition to conventional corticosteroid therapy, it is important to evaluate serum vitamin D level in OLP patients. And if the levels are deficient, vitamin $\mathrm{D}$ supplements can be added to the treatment regimen which could provide promising results. Majority of the population are vitamin D deficient, maybe because of increased trend of indoor games and use of sunscreen. Thus, People should be educated to understand the importance of sun exposure, which helps in enhancing overall immune status of an individual.

\section{REFERENCE}

1. Ahmed, S. A. (2019). The Role of Serum Vitamin D Deficency in oral Lichen Planus Case Control Study. Diyala Journal of Medicine, 17(2), 189198.

2. Razi, A., Mohiuddin, S., Karim, A. A., \& Iqbal, A. (2018). Vitamin D As An Adjuvant Therapy To Cure Oral Lichen Planus In Peri-Menopausal Women. Pakistan Oral \& Dental Journal, 38(4), 399-403.

3. Golizadeh Narges, pirzadeh Fatemeh, MirzaiiDizgah. (2020). Relationship between salivary vitamin D deficiency and oral lichen planus, 1-3

4. Varma, R. B., Valappila, N. J., Pai, A., Saddu, S. C., \& Mathew, N. (2014). Oral lichen planus: Is vitamin D deficiency a predisposing factor? A case report. IJSS, 2(7), 230-232.
5. Nazeer, J., Singh, S., Jayam, C., Singh, R., \& Iqubal, M. A. (2020). Assessment of the Role of Vitamin D in the Treatment of Oral Lichen Planus. The Journal of Contemporary Dental Practice, 21(4), 390-395.

6. Gupta, A., Mohan, R. P. S., Kamarthi, N., Malik, S., Goel, S., \& Gupta, S. (2017). Serum Vitamin D Level in Oral Lichen Planus Patients of North India-A Case-control Study. Journal of Dermatologic Research and Therapy, 1(2), 19-35.

7. Bahramian, A., Bahramian, M., Mehdipour, M., Falsafi, P., Khodadadi, S., Tabriz, F. D., \& Deljavanghodrati, M. (2018). Comparing vitamin D serum levels in patients with oral lichen planus and healthy subjects. Journal of Dentistry, 19(3), 212-216.

8. Gupta, J., Aggarwal, A., Asadullah, M., Khan, M. H., Agrawal, N., \& Khwaja, K. J. (2019). Vitamin $\mathrm{D}$ in the treatment of oral lichen planus: A pilot clinical study. Journal of Indian Academy of Oral Medicine and Radiology, 31(3), 222-227.

9. Tak, M. M., \& Chalkoo, A. H. (2017). Vitamin D deficiency--a possible contributing factor in the aetiopathogenesis of Oral lichen planus. Journal of Evolution of Medical and Dental Sciences, 6(66), 4769-4773.

10. Fini, B. (2020). The Association of Trace Elements and Vitamins with Lichen Planus: Review Article. 4(5), 3-9

11. Bikle, D. (2015). Vitamin D Metabolism, Mechanism of Action, and Clinical Applications, 20(3), 1-21

12. Shen, H., Liu, Q., Huang, P., Fan, H., Zang, F., Liu, M., ... \& Yang, J. (2020). Vitamin D receptor genetic polymorphisms are associated with oral lichen planus susceptibility in a Chinese Han population. BMC Oral Health, 20(1), 26.

13. Zhao, B., Li, R., Yang, F., Yu, F., Xu, N., Zhang, F., .. \& Du, J. (2018). LPS-induced vitamin D receptor decrease in oral keratinocytes is associated with oral lichen planus. Scientific reports, 8(1), 1-9.

14. Du, J., Li, R., Yu, F., Yang, F., Wang, J., Chen, Q., ... \& Zhang, F. (2017). Experimental study on $1,25(\mathrm{OH}) 2 \mathrm{D} 3$ amelioration of oral lichen planus through regulating $\mathrm{NF}-\kappa \mathrm{B}$ signaling pathway. Oral diseases, 23(6), 770-778.

15. Thum-Tyzo, K., Petkowicz, B., Tyzo, B., Pedowska, M., \& Dziedzic, M. (2014). OI0378 Vitamin D3 and oral health in patients with lichen planus. Oral Surgery, Oral Medicine, Oral Pathology and Oral Radiology, 117(5), e385.

16. Motahari, P., Azar, F. P., \& Rasi, A. (2020). Role of Vitamin D and Vitamin D Receptor in Oral Lichen Planus: A Systematic Review. Ethiopian Journal of Health Sciences, 30(4):615-622. 